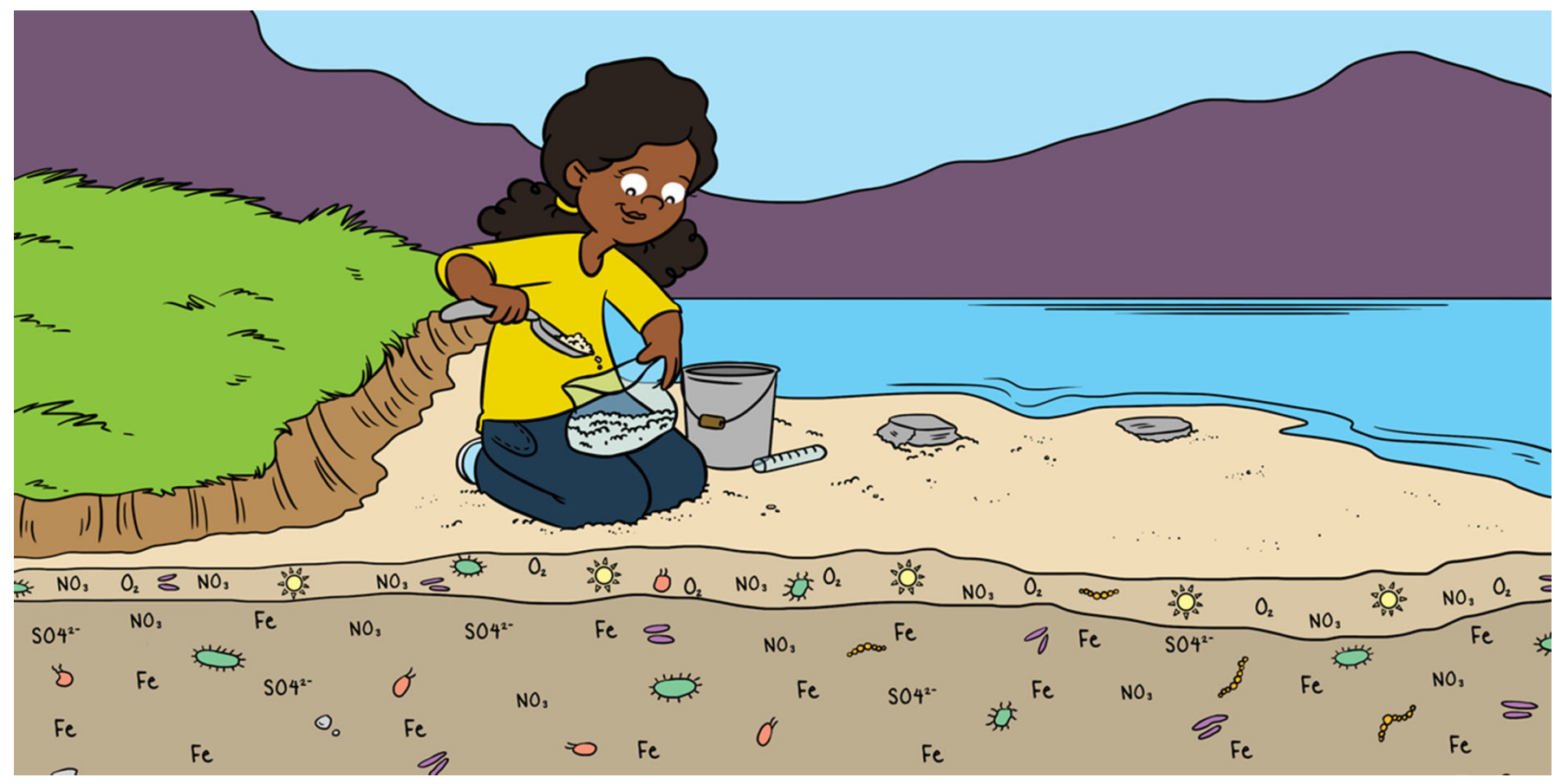

\title{
SHARING ELECTRONS: AN EXTRAORDINARY FRIENDSHIP BETWEEN BACTERIA
}

Julia M. Otte ${ }^{1,2,3^{*}}$

${ }^{1}$ Helmholtz - Max Planck Joint Research Group for Deep-Sea Ecology and Technology, Alfred Wegener Institute Helmholtz Centre for Polar and Marine Research, Bremerhaven, Germany

${ }^{2}$ Helmholtz - Max Planck Joint Research Group for Deep-Sea Ecology and Technology, Max Planck Institute for Marine Microbiology, Bremen, Germany

${ }^{3}$ Department of Geomicrobiology, Center for Applied Geoscience, University of Tübingen, Tübingen, Germany

YOUNG REVIEWERS:

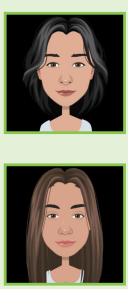

MARIANA

AGE: 15

ZARA

AGE: 14
Did you know that iron is one of the most important elements on Earth? It is assumed that life evolved close to iron sources. This means that the earliest life forms-and therefore oldest creatures-were able to use iron to obtain energy the way we use food. These tiny organisms are called iron microorganisms and can occur in sediments, which are mainly muddy sand. But less was known about where iron microorganisms live in these sediments-are they located close to the water surface or deep in the sediment? In this study, a team from the University of Tübingen investigated the distribution and variety of iron microorganisms. The scientists discovered that iron microorganisms live independent from their favorite foods: iron, oxygen, and light! This independence might be explained by an unexpected extraordinary friendship with a "living cable." Are you curious about what a living cable is? 


\section{MARINE SEDIMENT}

Rock and soil particles transported from coastal areas into the ocean by wind, ice, and rivers, as well as the remains of marine organisms.

\section{GEOCHEMICAL GRADIENT}

The difference between two compartments (upper and deeper sediment layers, in our case) in relation to the amount of substance like oxygen or light, or the temperature, pressure, or salt concentration.

\section{CELLULAR RESPIRATION}

The process that all living organisms use to create the energy they need to live. It involves the transfer of electrons from an electron donor (high energetic compound) to an electron acceptor (less energetic compound), resulting in the release of energy.

\section{DID YOU KNOW THAT SOME BACTERIA CAN "EAT" IRON?!}

Microorganisms are microscopic life forms that include bacteria, archaea, fungi, algae, protozoa, and viruses. In this study, I focused on bacteria. Bacteria live in our stomachs and on our skin, but also live everywhere else: from the deepest parts of the Earth's crust to high up in the clouds, and they even manage to live under the ice of the Antarctic or in hot springs. One teaspoonful of marine sediment contains more than a billion bacteria! Although bacteria are so small, there are so many of them that they have a huge impact on our environment.

To survive in such diverse environments, species of bacteria have evolved to "eat" many different things to obtain the energy they need to survive. The ones I will focus on in this article like iron! Iron bacteria are widespread in our environment. After oxygen, silicon, and aluminum, iron is one of the most common elements on Earth. Iron bacteria were essential for the beginning of life on Earth and might also be important on other iron-containing planets, such as Mars.

Iron bacteria can use iron to generate energy for their growth, and in doing so they produce waste products in the form of brownish iron minerals [1], commonly known as rust. So far, three groups of iron bacteria have been found to form iron minerals. One group is light-dependent, meaning they need light to survive, the second group is oxygen-dependent, and the third group is nitrogen-dependent [1].

Some iron bacteria live in coastal sediments, which are mainly muddy sand. Typical coastal sediment is usually made up of layers following geochemical gradients [2] (Figure 1). In the upper sediment layers that can be reached by sunlight, oxygen, and a lot of organic substances can be detected. In the deeper sediment layers there is less light and oxygen, but it is still possible to measure a bit of nitrate, organic substances, iron, iron minerals, and sulfate. These specific layers are mainly formed by the food preferences of the different sediment bacteria present at each sediment layer.

\section{HOW DO BACTERIA GET ENERGY FROM FOOD?}

To explain my research findings, we first need to go into a little more detail about the process by which bacteria get energy from their chosen food. At the cellular level, the process that all living things, including bacteria, go through to generate the energy they need to grow is called cellular respiration. At the smallest molecular level, this involves the exchange of electrons, which are the small pieces of an atom that have a negative electrical charge. In principle, 
Figure 1

Geochemical gradients in marine sediments. The layered structure of typical coastal sediments is shown with an actual sediment core containing marine coastal sediment from the Danish coast (Norsminde Fjord, Denmark) is shown in the center. The upper layer is brownish from the organic food and the deeper layer is blackish from the iron minerals. The presence of electron acceptors and electron donors in the sediment layers is shown on the left and right of the core, with the general location of various substances in the gradient indicated by the colored bars. In the upper layers of the sediment, light-, oxygen-, and organic food-dependent reactions take place, while further down in the sediment, the processes depend on nitrate, iron, and iron minerals. $e^{-}$, electrons: $\mathrm{O}_{2}$, oxygen

\section{ELECTRON DONOR}

A chemical substance that releases electrons to other compounds during a half reaction of cellular respiration. For example: organic substances or iron.

\section{ELECTRON ACCEPTOR}

A chemical substance that accepts electrons transferred to it from another compound during a half reaction of cellular respiration. For example: oxygen, nitrate, sulfate, iron minerals.

\section{e--Acceptor}

e--Donor/

\section{Energy Source}
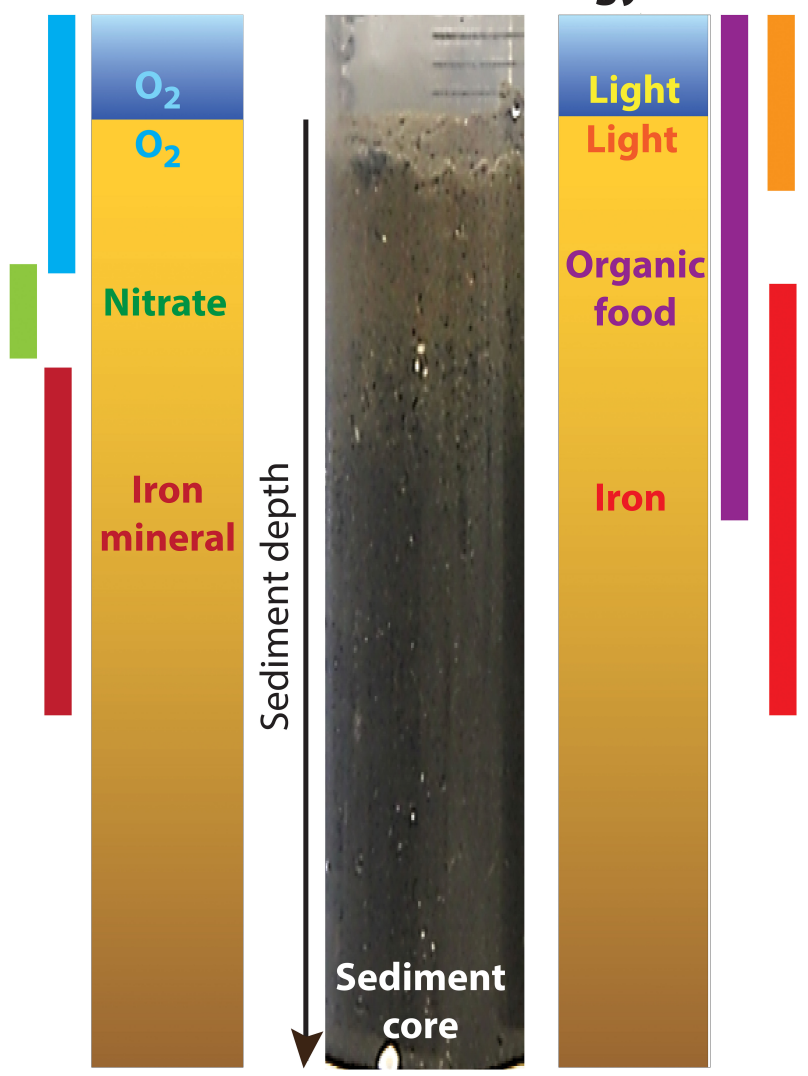

Figure 1

one food source for bacteria is what is called an electron donor (it donates electrons) and another source called the electron acceptor (it accepts electrons). While typical electron donors in sediments are soluble iron or organic substances from, e.g., dead organisms, typical electron acceptors are oxygen, nitrate, or iron minerals (Figure 1). The degradation of organic substances using oxygen provides the highest amount of energy and, as a result, oxygen is typically used up first, followed by nitrate, and then iron minerals [2].

So far, we know that iron bacteria-and all other organisms-need an electron transfer reaction to gain energy. Iron bacteria receive electrons from iron (the electron donor) and give the electrons to oxygen (the electron acceptor) [1]. In summary, this electron transfer from iron to oxygen allows the bacteria to receive energy for cell growth. This shows that bacteria are really smart: they use the energy differences of the electrons in iron (high potential) and in oxygen (low potential) to generate energy. You can compare it with a natural waterfall and a hydropower plant. The electrons from iron with a high energy potential fall down to oxygen with a lower energy potential (like a waterfall). During this process the iron bacteria can run their turbines (like in a hydropower plant) and produce energy. For iron-bacteria the electron transfer occurs at the cell membrane, where they produce 
Figure 2

The expected and measured distributions of bacteria in coastal sediments. (A) We expected that, when we looked at all typical sediment bacteria, we would see the different types of bacteria (shown on the right) distributed according to the gradients of substances they need to create energy (e.g., light, oxygen, and sulfate). The panel labeled "geochemical gradients" shows the amounts of the indicated substances as triangles, with the wide part representing a greater concentration of the substance and the narrowing of the triangle showing decreasing concentration. We detected that about $75 \%$ of the bacteria are orientated according to the gradients. When a huge amount of oxygen is available a lot of oxygen-dependent bacteria can be found, when less oxygen is present almost no oxygen-dependent bacteria is detectable. (B) When we looked at just the three types of iron bacteria, however, we found that they do not follow the expected distribution in the sediment and instead are found throughout all the sediment layers.

\section{A) General distribution of bacteria in marine sediments}

Expected distribution

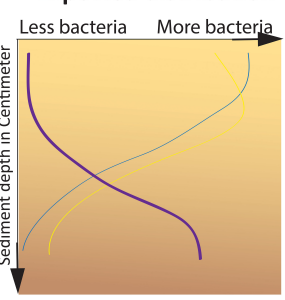

Detected distribution
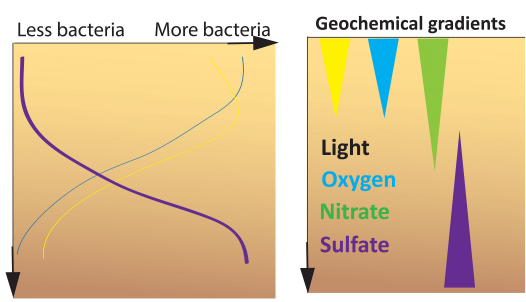

Selection of sediment bacteria

Light-dependent bacteria

Oxygen-dependent bacteria

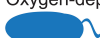

Sulfate-dependent bacteria

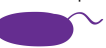

B) Distribution of iron bacteria in sediments

Expected distribution
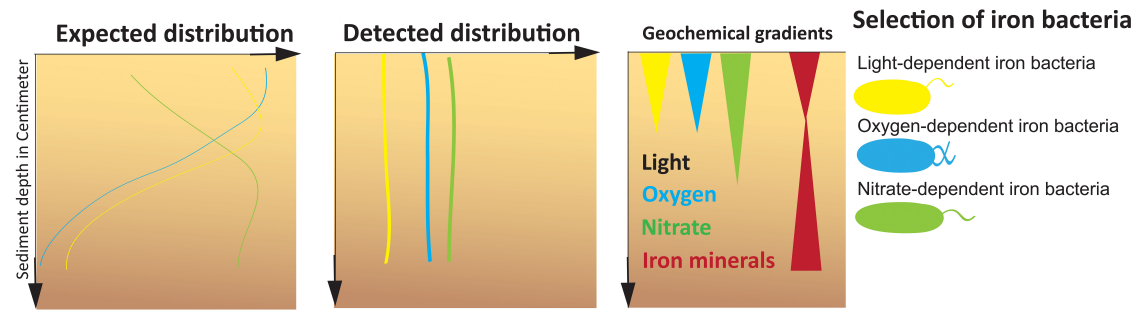

Figure 2

the iron minerals. It is important to mention that the cell membrane of iron bacteria is equipped with a special biochemical machinery (called wires) to transport electrons along their cell membranes [3]. Of course, the electron transfer reaction of iron bacteria is much more complex and therefore different in comparison to other sediment bacteria and other organisms.

\section{UNEXPECTED DISTRIBUTION OF IRON BACTERIA IN COASTAL SEDIMENTS}

Until recently, the natural distribution of iron bacteria in the layers of coastal sediments was unknown. Therefore, equipped with rubber boots, gloves, buckets, bottles, and syringes, a research team from the University of Tübingen spent 3 years collecting various sediment samples in Denmark on the Baltic Sea coast to study the distribution of iron bacteria in typical coastal sediment. They analyzed the types of bacteria in the samples and the amounts of iron, oxygen, and nitrate that were present in the upper few centimeters $(0-5 \mathrm{~cm})$ of the sediment. At the surface layer of the sediment, I detected oxygen which decreased within the deeper sediment layers [4] (Figure 2A). I expected to see that this oxygen gradient also determined the types of bacteria living in all sediment layers. Then, we looked for all typical sediment bacteria that are dependent on light and oxygen. Most of the light- and oxygen-dependent sediment bacteria were found living at the surface and less of them living in the deeper sediments, which is what my colleagues and me expected [4] (Figure 2A).

However, when specifically looking at all three types of iron bacteria, even those that were dependent on substances present in the surface layers of sediment like oxygen, nitrate, and sun light, my colleagues 
Figure 3

Why are iron bacteria distributed through all sediment layers? We explored several possible reasons why iron bacteria do not follow gradients in the sediment. (A) Physical mixing by waves or worms; (B) iron bacteria are "sleeping" and do not need nutrients; (C) iron bacteria can move throughout the layers; (D) iron bacteria find small bubbles filled with oxygen or nitrate; (E) iron bacteria can eat various "foods"; and (F) iron bacteria interact with cable bacteria which help them to exchange electrons. None of the explanations from (A) to (E) could explain the distribution. Instead, we suggest that iron bacteria can use the cable bacteria as, e.g., electron acceptors. This allows the iron bacteria to live independent from the geochemical gradients of, e.g., oxygen, thanks to the help of their friends - the cable bacteria. $\mathrm{e}^{-}$, electrons; $\mathrm{O}_{2}$, oxygen.
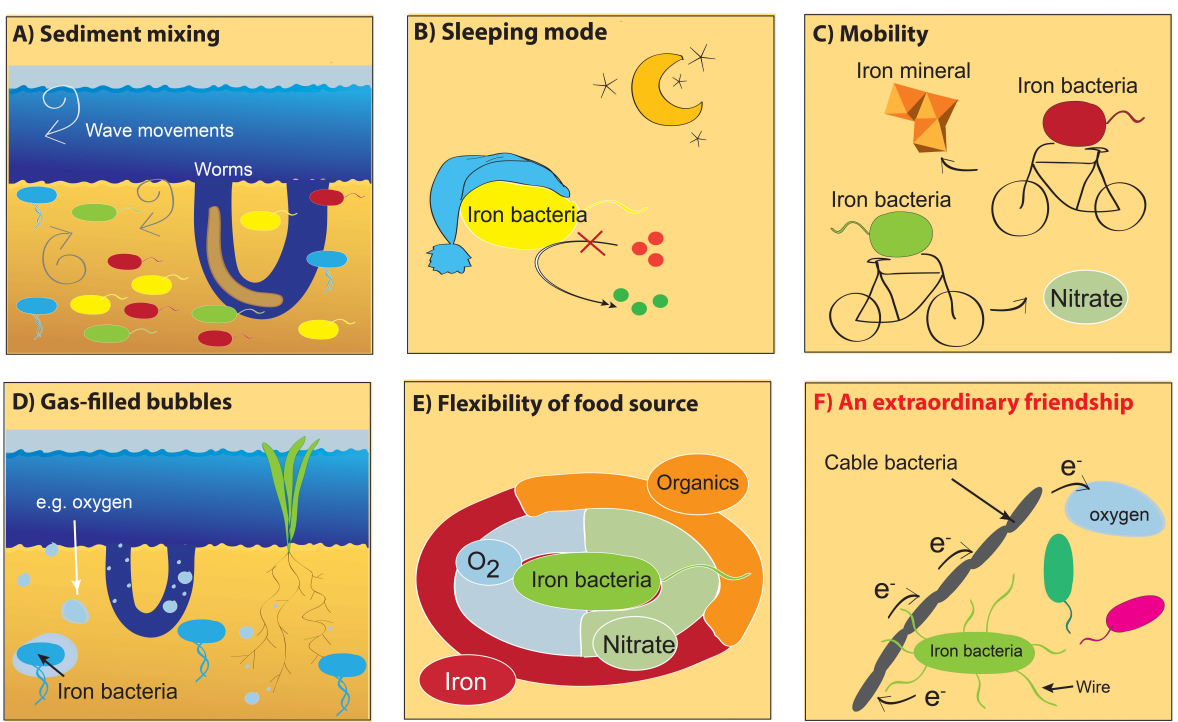

Figure 3

and me were really surprised to find all three types of iron bacteria were equally mixed through all the sediment layers [4] (Figure 2B). This means that iron bacteria behave differently than most of the sediment bacteria and do not orient themselves according to the gradients of oxygen, nitrate, or sun light when choosing their favorite spot to live. Since this was a very interesting result, I tried to figure out why iron bacteria behave differently than other types of bacteria and can live in all sediment layers.

\section{HOW CAN WE EXPLAIN THE UNEXPECTED DISTRIBUTION OF IRON BACTERIA IN SEDIMENTS?}

Several hypotheses could explain the distribution of iron bacteria throughout the layers of sediment (Figures 3A-E).

(A) Might the iron bacteria become mixed through the sediment layers by worm activity or wave movements? My colleagues and I are not inclined toward this hypothesis because mixing should affect all sediment bacteria, so this does not explain why only iron bacteria were found throughout all layers.

(B) Might the iron bacteria be in a kind of "sleep" state in some of the layers, resting until better conditions are available? However, the iron bacteria were really active and were not "sleeping," so this hypothesis cannot explain the distribution pattern of bacteria across the sediment.

(C) Maybe the iron bacteria are mobile, and able to travel through the sediment layers? The ability to move is not a special feature of iron bacteria; although a lot of sediment community members are mobile. 
(D) Can iron bacteria use oxygen- or nitrate-filled "bubbles" in deeper sediment layers as a food source? The small, gas-filled bubbles of oxygen or other food sources could not explain the distribution of iron bacteria alone. So, this hypothesis was also ruled out.

(E) Are iron bacteria flexible with their food source? Again, a flexible diet could not explain the distribution of all the different iron bacteria along the sediment alone.

When realizing that the behavior of the iron bacteria could not be explained with any of these hypotheses, my colleagues and I had to continue their research. And it became more and more exciting!

\section{DO THE FASCINATING ELECTRIC CABLE BACTERIA PLAY A ROLE HERE?}

In 2010, a team of scientists from the Center for Electromicrobiology in Denmark discovered unusual electric bacteria [5] which have a multicellular structure containing thousands of cells in line. These extraordinary bacteria are called cable bacteria. In contrast to other bacteria, cable bacteria can transport electrons over long distances (around $5 \mathrm{~cm}$ !) in their multicellular cable and function like electric cables in the sediments! So, the hypothesis to explain the distribution of iron bacteria along the sediment might rely on the electric cable bacteria. Indeed, cable bacteria and iron bacteria were living together in the same sediment layers [4] (Figure 3F). Why is it an extraordinary friendship? Remember that iron bacteria need an electron transfer reaction to gain energy and that iron bacteria are equipped with special biochemical machinery (also called wires) on their cell membranes that helps them to provide or grab electrons [3]. Using this biochemical machinery, iron bacteria can transfer electrons to the cable bacteria when they do not have oxygen available as an electron acceptor! The cable bacteria can act as an electron acceptor for iron bacteria, picking up the electrons from the iron bacteria and moving them through the cable to the sediment surface. At the sediment surface, there is a lot of oxygen that can act as a normal electron acceptor. Thanks to the extraordinary friendship with cable bacteria, oxygen-breathing iron bacteria can thus survive in all sediment layers, independent of oxygen being present in the sediment layer where they live and use the cable bacteria as a kind of a snorkel! Nitrate- and light-dependent iron bacteria can also live independent of their food sources in all sediment layers (Figure 3B), possibly using the same mechanism.

\section{AN EXTRAORDINARY MICROBIAL FRIENDSHIP}

The relationship between iron bacteria and cable bacteria needs more evidence to confirm this extraordinary friendship. However, with this study my colleagues and I already showed that iron bacteria are likely using a unique strategy to survive in all sediment layers, independently 
of their vital food source being present! Iron bacteria use their special ability to transport electrons on their cell membranes-which is not the case in most other bacteria-and they can interact with the cable bacteria. So, the extraordinary friendship of iron bacteria and cable bacteria could explain the special distribution of iron bacteria in marine sediments. The surprising bacterial distribution and unexpected relationship of the iron bacteria and cable bacteria throughout all sediment layers also has a positive effect on the entire microbial community, since the iron bacteria can live in deeper sediment layers independent of, e.g., light and oxygen and can help other organisms with the production of their iron minerals. For example, toxic substances can stick to iron minerals and are no longer harmful for others. In this way, the extraordinary bacterial friendship can have a number of other positive side effects on the ecosystem. Of course, further research is needed to understand the exact relationships between the two friends. Scientists learned that cooperation, even at the small scale of bacteria, can help organisms to survive. This type of positive interactions, when both bacterial groups gain something when working together, occurs through the tree of life.

\section{ORIGINAL SOURCE ARTICLE}

Otte, J. M., Harter, J., Laufer, K., Blackwell, N., Kappler, A., and Kleindienst, S. 2018. The distribution of active iron cycling bacteria in marine and freshwater sediments is decoupled from geochemical gradients. Environ. Microbiol. 20:2483-99. doi: 10.1111/1462-2920. 14260

\section{REFERENCES}

1. Weber, K. A., Achenbach, L. A., and Coates, J. D. 2006. Microorganisms pumping iron: anaerobic microbial iron oxidation and reduction. Nat. Rev. Microbiol. 4:752-64. doi: $10.1038 /$ nrmicro1490

2. Canfield, D. E., and Thamdrup, B. 2009. Towards a consistent classification scheme for geochemical environments, or, why we wish the term 'suboxic' would go away. Geobiology 7:385-92. doi: 10.1111/j.1472-4669.2009.00214.x

3. Reguera, G., McCarthy, K. D., Mehta, T., and Nicoll, J. S. 2005. Extracellular electron transfer via microbial nanowires. Nature 435:1098-109. doi: 10.1038/nature 03661

4. Otte, J. M., Harter, J., Laufer, K., Blackwell, N., Kappler, A., and Kleindienst, S. 2018. The distribution of active iron cycling bacteria in marine and freshwater sediments is decoupled from geochemical gradients. Environ. Microbiol. 20:2483-99. doi: 10.1111/1462-2920.14260

5. Pfeffer C., Larsen, S., Song, J., Dong, M., Besenbacher, F., Meyer, R. L., et al. 2012. Filamentous bacteria transport electrons over centimetre distances. Nature 491:218-21. doi: 10.1038/nature11586 
SUBMITTED: 16 March 2020; ACCEPTED: 10 November 2020;

PUBLISHED ONLINE: 07 December 2020.

EDITED BY: Sanae Chiba, Japan Agency for Marine-Earth Science and Technology (JAMSTEC), Japan

CITATION: Otte JM (2020) Sharing Electrons: An Extraordinary Friendship Between Bacteria. Front. Young Minds 8:543259. doi: 10.3389/frym.2020.543259

CONFLICT OF INTEREST: The author declares that the research was conducted in the absence of any commercial or financial relationships that could be construed as a potential conflict of interest.

COPYRIGHT () 2020 Otte. This is an open-access article distributed under the terms of the Creative Commons Attribution License (CC BY). The use, distribution or reproduction in other forums is permitted, provided the original author(s) and the copyright owner(s) are credited and that the original publication in this journal is cited, in accordance with accepted academic practice. No use, distribution or reproduction is permitted which does not comply with these terms.

\section{YOUNG REVIEWERS}

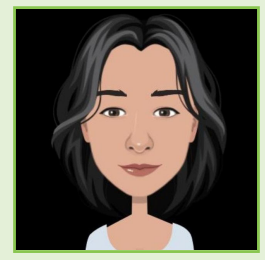

\section{MARIANA, AGE: 15}

Hi! My name is Mariana and I am 15 years old. I like reading books, spending time with animals, and swimming. I consider every day brings an opportunity for me to learn something new and for being happy.

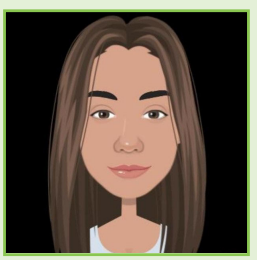

\section{ZARA, AGE: 14}

My name is Zara and I am 14 years old. In my spare time, I enjoy reading, helping my community, and playing volleyball. I think it is important to work hard for achieving our dreams and for being a better person every day.

\section{AUTHOR}

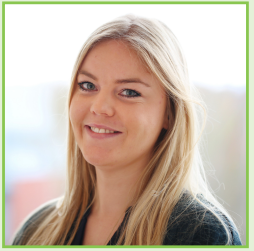

\section{JULIA M. OTTE}

I was trained in Bio Science and Geo Science at the University of Heidelberg (Germany) and the University of Freiburg (Germany), with a specialization in Molecular Biology, Biochemistry, and Microbiology. In 2018, I finished my Ph.D. at the University of Tübingen (Germany) with a specialization in Geomicrobiology and Microbial Ecology, with a focus on iron-cycling bacteria in marine sediments. Since 2018, I have been in the HGF-MPG Group for Deep-Sea Ecology and Technology at the Alfred Wegener Institute Helmholtz Centre for Polar and Marine Research in Bremerhaven and at the Max Planck Institute for Marine Microbiology in Bremen (Germany). I am currently working on the impacts of deep-sea mining in the Pacific Ocean on metal-cycling microorganisms on the 4,000 m deep seafloor. *julia.otte@awi.de; jotteampi-bremen.de 